\title{
The Relationship Listening Intensively Toward Ability to Write News Content by Student Eighth Grade of SMP Negeri 1 Atap Tampahan in Academic Year 2017/2018
}

\author{
Mariatih Saragih., M. Pd; Erlinawati Situmorang., M.Pd \\ Faculty of Teacher's Training and Education Sisingamangaraja XII University of Tapanuli
}

\begin{abstract}
This study aims to determine The Relationship Listening Intensively Toward Ability to Write News Content by Student Eighth Grade of SMP Negeri 1 Atap Tampahan in Academic Year 2017/2018.The Population of this Study were the Student Eighth Grade of SMP Negeri 1Atap Tampahan in Academic Year 2017/2018.A Population of Students 101 and samples taken 50\% which 50 students.the writer use random sampling to determine the sample. The Result of data analysis show that $r_{x y}=$ $0,32300 r_{x y}>r_{\text {table. }}$. The result moment at significant level $5 \%=0$, 2732. Means that the relationship intensively listening ability variables with the ability to write news content by students has a significant correlation. The result of data analysis shows that the intensively listening ability obtained with an average value $=84.82$ standard deviation $=5.74$. Namely, very good category, 26 students (52\%), who have score in both categories as 23 students $(46 \%)$ and students who have values in the well category 1 student (2\%). None of the students have score in lower categories. While the ability to write news content obtained value with an average $=79.9$ standard deviation $=7.9681$. 19. Students $(38 \%)$, who have good category and 28 students (56\%) who have value in well category,3 student (6\%) who have value in enough category. None of the students have lower score and less good categories. Based in normality test and homogeneity test obtained normal distribution data. From the calculations show it can be known $r_{\text {caunt }}>r_{\text {tablel }}=$ 0.32300> 0.2732. Thus, $H_{o}$ (null hypothesis) is rejected and $H_{a}$ (alternative hypothesis) is accepted. It can be concluded that The Relationship Listening Intensively Toward Ability to Write News Content by Student Eighth Grade of SMP Negeri 1 Atap Tampahan in Academic Year 2017/2018. has a significant correlation.
\end{abstract}

Keywords - Intensively Listening Skills, Writing, News.

\section{INTRODUCTION}

In learning the language, the first activity that students do is listen to the sounds of language learned, either in the form of direct greeting or through media assistance. In this case, listening ability is defined as the ability to grasp and understand spoken language and which is received through the auditory channel. Listening and writing are closely related, as they are means of understanding information in communication activities. As one of the four aspects of language skills, writing is also inseparable from teaching and learning activities in schools. Writing skills is one of the competency standards contained in Junior High School curriculum in the field of Indonesian language studies. This skill is needed by students in the learning process, whether in writing personal experience, adapt, and even write something that heard through the results of a recording. For that,serious attention to writing skills is essential. Based on the above explanation, listening and writing skills have a close relationship. If we want to re-write what we see, we hear, we feel, and we think it takes a listening activity. In other words, through listening activities, one can express his thoughts and ideas into a written form to achieve purposes . Similarly, in writing the news heard. To write the news well and correctly depends on the sensitivity and concentration of students in listening to the news. The average student's learning outcomes have not been very satisfactory in terms of both the content and the writing. In other hand student learning outcomes in writing back the news is still classified in the low category. In world of education, we often find many students who do not have the ability to rewrite what they have seen.

\section{LITERATURE REVIEW}

\section{Defenition of Listening}

Listening is a process of attentively to what the speaker is saying to get information or messages to be delivered to the listener. Anwar (2005:332) menyatakan, "simak:menyimak adalah mendengarkan, memperhatikan baik-baik apa yang diucapkan atau yang dibaca orang (Listening is paying close attention to what people say or read) Kamus Besar Bahasa Indonesia (1991:941), "Simak, menyimak yaitu (1) mendengarkan (memperhatikan) baik-baik apa yang diucapkan atau dibaca orang;(2) 
meninjau(memeriksa,mempelajari) dengan teliti”.( Listenening (1) listen (pay attention) well what people say or read, (2) review (check, study) carefully

H.G. Tarigan (1994:28) menyatakan:

"Menyimak adalah suatu proses kegiatan mendengarkan lambing-lambang lisan dengan penuh perhatian, pemahaman, apresiasi serta interpretasi untuk memperoleh informasi, menangkap isi atau pesan serta memahami makna komunikasi yang telah disampaikan oleh sang pembicara melalui ujaran atau bahasa lisan". ("Listening is a process of oral symbols with full attention, understanding, appreciation and interpretation to obtain information, capture the content or message and understand the meaning of communication that has been conveyed by the speaker through speech or spoken language")

Based on the above opinion, it can be concluded that listening is an activity undertaken to listen with full attention, understanding, and interpretation to obtain something.

\section{Types of Listening}

Menurut Tarigan (1994:35), berdasarkan cara penyimakan dikenal dua jenis menyimak, yaitu: 1) Menyimak intensif, penyimak memahami secara terperinci, teliti dan mendalam bahan yang disimak. Menyimak intensif mencakup menyimak kritis, menyimak konsentratif, menyimak interogatif, dan menyimak selektif. 2) Menyimak ekstensif, penyimak memahami isi bahan simakan secara sepintas, umum dan garis-garis besar, atau butir- butir penting tertentu. Menyimak ekstensif meliputi menyimak sosial, menyimak sekunder, menyimak estetik, dan menyimak pasif. (based the two types of listening, namely: 1) Intensive listening, listening understand in detail, thorough and in-depth material being listened to. Intensive listening includes critical listening, concentrated listening, listening to interrogative, and selective listening. 2) Listening extensively, listeners understand the content of the material at a glance, general and outline, or certain points of importance. Extensive listening includes social listening, secondary listening, listening aesthetics, and passive listening. Menurut Kamus Besar Bahasa Indonesia (1991:383), "Intensif adalah sungguh-sungguh dan terus-menerus dalam mengerjakan sesuatu sehingga memperoleh hasil yang optimal. ("Intensive is really and continuously in doing things to obtain optimal results). Anwar (2005:135) menyatakan, "Intensif adalah secara sungguh-sungguh dan berulang-ulang dalam melakukan sesuatu hingga memperoleh hasil yang maksimal". (Intensive is seriously and repeatedly in doing something to get maximum results".)

Based on the above opinion, it can be concluded that intensively is seriously and repeatedly in doing something to obtain optimal results. From the listening and intensive words interpreted separately, it can be concluded that intensive listening is an activity that is intentionally done to listen in earnest and constantly obtain optimal results (information).

\section{Defenition of Writing}

Writing is an attempt to convey a certain idea or concepts to others through writing and is a specific message to be conveyed to the reader. In writing, we know the extent of our ability on a topic. In the world of writing education can not be separated from the learning process, whether it is writing personal experience, adapt, even write something we hear through the results of a recording.( Writing or composing is essentially a transfer of thoughts or feelings into the symbolic form of language") Kamus Besar Bahasa Indonesia (1991:1079), "Menulis adalah melahirkan pikiran atau perasaan (seperti mengarang, membuat surat dengan tulisan, mengarang cerita, membuat surat, berkirim surat)". (Writing is giving birth to thoughts or feelings (such as making up, writing letters, writing stories, making letters, sending letters)

Tarigan (1986:21) juga menyatakan:

"Menulis diartikan juga sebagai kegiatan menurunkan atau melukiskanlambang-lambang grafik yang menggambarkan suatu bahasa yang dipahami oleh seseorang, sehingga orang lain dapat membaca lambanglambang grafik tersebut kalau mereka memahami bahasa dan gambaran grafik itu".( "Writing is also interpreted as the activity of descending or depicting the graphic representations of a language that a person understands, so that others can read the graphic symbols if they understand the language and graphic picture)

Based on the above quotation, it can be concluded that writing is an activity done to describe, give birth or move thoughts and feelings, and ideas into the form of written language, so that readers can undrestand easy and clear.

\section{Defenition of News}

Semi (1995:9)menyatakan bahwa berita adalah fakta yang disampaikan kepada orang lain. Namun, tidak semua fakta masuk kedalam jenis berita, karena berita adalah laporan tercepat mengenai fakta atau ide terbaru yang benar,menarik, dan atau penting bagi sebagian besar khalayak,melalui media berkala seperti surat kabar, radio, televisi, maupun media online internet (Sumandiria 2005:65). ( news is a fact that is passed on to others. However, not all facts fit into the type of news, because news is the fastest report on the latest facts or ideas that are true, interesting, and or important to most audiences, through regular media such as newspapers, radio, television, and online internet media) From the definition can be concluded that the news is information about a recent event that is passed back to others through oral and written media. The information on the event or state of affairs is general in $\mathrm{fl}$ uence on the community. 


\section{RESEARCH METHODOLOGY}

The method used in this study is a descriptive method correlational approach that aims to describe the The Relationship Listening Intensively toward Ability to Write News Content by Student Eighth Grade of SMP Negeri 1 Atap Tampahan in Academic Year 2017/2018. Arikunto (2002: 239), Correlational approach aims to determine whether or not there is a relationship and if any, how closely the relationship and the meaning or not the relationship. This study aims to see a significant relationship between the ability to listen intensively with the ability to write news content that listened.

\section{Population and Sample}

The population of this study is all Student Eighth Grade of SMP Negeri 1Atap Tampahan in Academic Year 2017/2018. The sample of research taken $50 \%$ that is 50 student as population. Technique used is random technique (random) by way drawing.

\section{RESULT AND DISCUSSION}

Based on the data obtained the intensively listening table it is known that the number of samples 50 students obtained from the population 101 students by Student Eighth Grade of SMP Negeri 1 Atap Tampahan in Academic Year 2017/2018, so the sample used 50 students from the population. Data collection through intensively listening skills assessment test is 23 items with multiple choice a, b, c, and d. The test results obtained from intensively listening skills by junior high school students Eighth Grade of SMP Negeri 1 Atap Tampahan $=84.82$ with very good category. Data collection in ability to write news content obtained by assigning to students to write news content, assessment of writing news content using five indicators namely, the suitability of the content with the title, the completeness of news items $(5 \mathrm{~W}+1 \mathrm{H})$, demands, diction, and use of EYD (Ejaan Yang Suah Disempurnakan). Test results obtained from the ability to write news content by junior high school Eighth Grade of SMP Negeri 1 Atap Tampahan $=76.7$ with good category. Then we see from frequency distribution table, it is known that the intensive listening ability majority of students has good Score (26\%) (52\%), 23 students in good category (46\%), 1 student who have good enough category $(2 \%)$, while lower category not found. the ability to write news content is dominated by students who have good Score (15\%) (29\%), 29 students in good category (58\%), 6 students who have good enough category $(12 \%)$. None of the students have score in the lower categories. From the calculation of correlation with rough figures obtained $r_{\text {caunt }}$ $=0.2768$ while $\mathrm{r}_{\text {table }}$ with $\mathrm{N}=50$ at $5 \%$ significant level $=$ $0.2732 . r_{\text {caunt }}>r_{\text {table }}(0,32300>0,2732)$ hence the research hypothesis is proposed there is a significant relationship between intensively listening ability with the ability to write news content Student Eighth Grade of SMP Negeri 1 Atap Tampahan in Academic Year 2017/2018

\section{CONCLUSION}

After Analyzing data the following conclusions are derivided.

1. Intensively listening skills by Student Eighth Grade of SMP Negeri 1 Atap Tampahan in Academic Year 2017/2018 in very good category with average intensively listening ability $(\mathrm{X})=84.82$

2. The Ability to write news content by Student Eighth Grade of SMP Negeri 1 Atap Tampahan in Academic Year 2017/2018 havegood category with the average value of writing news content $(Y)=79,9$ is in good category.

3. There is a positive and significant relationship between intensively listening ability toward the ability to write news by Student Eighth Grade of SMP Negeri 1 Atap Tampahan in Academic Year 2017/2018 $=0.32300$.

\section{REFERENCES}

[1] Ali, L. (1991. Kamus Besar Bahasa Indonesia. Jakarta: Balai Pustaka.

[2] Arikunto. (2012). Dasar-Dasar Evaluasi Pendidikan. Edisi Ke-2. Jakarta: Bumi Aksara .

[3] Ezyzurriyati. (2014). [Hakikat Menyimak Pengertian Menyimak]. Retrieved from http://www.co.id/

[4] Tarigan, H. (1994). Menyimak Sebagai Suatu Keterampilan Berbahasa. Bandung : Angkasa.

[5] Tarigan, H. (1995). Menyimak Sebagai Suatu Keterampilan Berbahasa. Bandung : Angkasa

[6] Tarigan, H (1996). Menyimak Sebagai Suatu Keterampilan Berbahasa. Bandung : Angkasa

[7] Tarigan, H. (1982). Menulis Sebagai Suatu Keterampilan Berbahasa. Bandung: Angkasa 